\title{
EDUKASI PENGGUNAAN e-FILING MELALUI PROGRAM RELAWAN PAJAK 2019
}

\author{
D. Tialurra Della Nabila ${ }^{1}$, I Dewa Ketut Yudha $S^{2}$, Abdul Manan ${ }^{3}$ \\ 1Program Studi S1 Akuntansi Universitas Mataram \\ 2,3Program Studi D3 Perpajakan Universitas Mataram \\ tialurradellanabila@unram.ac.id
}

\begin{abstract}
ABSTRAK. Reformasi Teknologi Informasi Perpajakan adalah salah satu upaya yang dilakukan oleh Direktorat Jenderal Pajak (DJP) untuk meningkatkan kepatuhan pajak. Aplikasi e-Filing merupakan salah satu aplikasi yang tersedia di situs DJP Online yang dapat digunakan untuk melaporkan Surat Pemberitahuan (SPT) secara online dan real time. Kendala yang sering dihadapi oleh Wajib Pajak dalam penggunaan e-Filing adalah lupa EFIN, e-mail, dan jaringan internet yang lamban sehingga solusi yang ditawarkan adalah melalui Program Relawan Pajak. Pengabdian masyarakat ini meliputi Perekrutan, Pelatihan, Penugasan, dan Evaluasi Relawan Pajak. Pada Tahap Perekrutan diperoleh sebanyak 66 orang mahasiswa yang ditetapkan menjadi Relawan Pajak. Selanjutnya, Relawan Pajak mengikuti pelatihan dan Leveling Test. Sebanyak 28 orang ditugaskan di KPP Pratama Mataram Barat, 19 orang ditugaskan di KPP Pratama Mataram Timur, dan 19 orang ditugaskan di KPP Pratama Praya. Pada Tahap Evaluasi diperoleh hasil bahwa dari ketiga lokasi asistensi tersebut seluruhnya dinyatakan berhasil mencapai jumlah target penerimaan SPT Tahunan melalui e-Filing.
\end{abstract}

Kata Kunci: e-Filing, Relawan Pajak, Kepatuhan Pajak

ABSTRACT. Taxation Information Technology Reform is one of the efforts made by Direktorat Jenderal Pajak (DJP) to improve tax compliance. The e-Filing application is one of the applications available on the DJP Online site that can be used to report Surat Pemberitahuan (SPT) online and real time. The obstacles often faced by Taxpayers in using e-Filing are forgetting EFIN, e-mail, and slow internet networks so that the solutions offered are through the Relawan Pajak Program. This society service includes the Recruitment, Training, Assignment and Evaluation of Relawan Pajak. In the Recruitment Phase 66 students were assigned to become Relawan Pajak. Furthermore, the Relawan Pajak attended the training and Leveling Test. A total of 28 students were assigned to KPP Pratama Mataram Barat, 19 students were assigned to KPP Pratama Mataram Timur, and 19 students were assigned to KPP Pratama Praya. In the Evaluation Phase, results were obtained that all three assistance locations were declared successful in reaching the target number of SPT Tahunan receipts through e-Filing.

Keyword: e-Filing, Relawan Pajak, Tax Compliance

\section{PENDAHULUAN}

Reformasi Undang-Undang Perpajakan di Indonesia dimulai pada tahun 1983, yaitu dengan merombak perundang-undangan perpajakan peninggalan kolonial Belanda menjadi lima paket undang-undang perpajakan yang baru. Reformasi ini mengubah sistem perpajakan Indonesia yang awalnya Official Assessment System menjadi Self Assessment System. Berbeda dengan sistem perpajakan terdahulu, pada sistem perpajakan Self Assessment kewenangan fiskus tidak lagi dominan melainkan hanya sebagai pengawas pelaksanaan perpajakan. Pada sistem ini, Wajib 
Pajak berperan aktif dalam pemenuhan kewajiban perpajakannya sendiri, meliputi penghitungan, pembayaran, dan pelaporan pajak. Setelah reformasi mendasar pada tahun 1983, pemerintah telah melaksanakan Reformasi Birokrasi, Reformasi Perpajakan Jilid I, Reformasi Perpajakan Jilid II, dan saat ini Reformasi Perpajakan Jilid III.

Target pendapatan negara pada RAPBN tahun 2019 sebesar Rp 2.142,5 triliun terdiri dari penerimaan perpajakan sebesar Rp 1.781 triliun, penerimaan negara bukan pajak sebesar Rp 361,1 triliun, dan penerimaan hibah sebesar Rp 0,4 triliun. Dari ketiga sumber pendapatan negara tersebut, penerimaan dari sektor perpajakan memiliki kontribusi terbesar, yaitu lebih dari $80 \%$. Dengan demikian, pajak menjadi ujung tombak dalam pembangunan nasional. Direktorat Jenderal Pajak (DJP) merupakan institusi pemerintah di bawah Kementerian Keuangan yang berperan sebagai perumus dan pelaksana kebijakan dan standarisasi teknis di bidang perpajakan untuk meningkatkan pendapatan negara melalui peningkatan kepatuhan Wajib Pajak. Upaya konkret yang dilakukan DJP untuk peningkatan pelayanan melalui Reformasi Teknologi Informasi Perpajakan adalah dengan meluncurkan situs DJP Online yang merupakan pusat pelayanan perpajakan online untuk memudahkan Wajib Pajak untuk melaksanakan kewajiban perpajakannya.

Electronic Filing atau biasa disebut dengan e-Filing merupakan salah satu aplikasi perpajakan yang disediakan pada situs DJP Online untuk melaporkan Surat Pemberitahuan (SPT) secara elektronik dan real time. Untuk mendukung program tersebut, pada tahun 2017 Menteri Pendayagunaan Aparatur Negara dan Reformasi Birokrasi melalui Surat Edaran Nomor 24 Tahun 2017 mewajibkan ASN dan Anggota TNI/ Polri untuk menyampaikan SPT Tahunan PPh Orang Pribadinya dengan e-Filing. Pada tahun 2018 terjadi peningkatan penggunaan e-Filing dalam pelaporan SPT Tahunan PPh Orang Pribadi sebesar 21,6\%. Dari total SPT Tahunan PPh Orang Pribadi yang dilaporkan, sebanyak $80,13 \%$ menggunakan e-Filing. Berdasarkan Tweet sematan akun resmi Direktorat Jenderal Pajak (@DitjenPajakRI), diperoleh informasi bahwa keluhan yang paling sering disampaikan oleh Wajib Pajak mengenai aplikasi ini adalah lupa EFIN. Hal ini didukung oleh pernyataan pegawai pajak saat ditinjau langsung oleh Menteri Keuangan terkait kendala Wajib Pajak dalam penggunaan e-Filing, yaitu lupa EFIN, e-mail, dan jaringan internet yang tidak lancar.

Bencana gempa bumi yang secara berturut-turut mengguncang Pulau Lombok pada pertengahan tahun hingga akhir tahun 2018 mengakibatkan melemahnya perekonomian masyarakat dan berdampak terhadap sektor perpajakan. Pemerintah melalui Direktorat Jenderal Pajak (DJP) mengeluarkan kebijakan untuk keadaan kahar (force majeur) Pulau Lombok yang tertuang dalam KEP-209/PJ/2018 yang berisi keringanan beban dan dampak sosial berupa pengecualian sanksi pajak, perpanjangan batas waktu bayar dan pengajuan keberatan pasca bencana gempa. Wilayah kerja Kantor Wilayah DJP Nusa Tenggara (Kanwil DJP Nusra) meliputi NTB dan NTT, membawahi 12 KPP dan 12 KP2KP termasuk yang terkena dampak bencana di Pulau Lombok. Sebanyak 465.360 Wajib Pajak yang terdaftar di Pulau Lombok berhak mendapatkan keringanan hingga berakhirnya kondisi tanggap darurat.

Pada awal tahun 2019, capaian penerimaan SPT Tahunan PPh Orang Pribadi di KPP Mataram Barat hanya mencapai $20 \%$ dari target sebanyak 21.000 SPT. Permasalahan yang serupa juga dihadapi oleh KPP Pratama Mataram Timur dan KPP Pratama Praya. Ketiga KPP tersebut berada di Pulau Lombok. Tax Center Universitas Mataram sebagai mitra resmi Kanwil DJP Nusra berkomitmen untuk mewujudkan kesadaran perpajakan melalui kegiatan Tridharma Perguruan Tinggi. Edukasi dalam penggunaan aplikasi e-Filing kepada Wajib Pajak di Pulau Lombok sangat 
dibutuhkan untuk meningkatkan kepatuhan Wajib Pajak pasca bencana. Penerapan e-Filing sebagai sarana pelaporan SPT Tahunan yang diterapkan oleh KPP Pratama Mataram Timur berpengaruh positif terhadap tingkat kepatuhan Wajib Pajak (Amrul, 2016). Sehingga upaya yang dapat dilakukan untuk mencapai peningkatan kepatuhan tersebut adalah dengan pelaksanaan program Relawan Pajak. Menurut Observasi Kegiatan Relawan Pajak pada tahun 2017, manfaat yang dapat diperoleh oleh mahasiswa jika menjadi Relawan Pajak adalah dapat berkontribusi kepada negara, pengembangan kapasitas diri dan networking.

Salah satu tugas utama Relawan Pajak adalah asistensi e-Filing kepada Wajib Pajak Orang Pribadi untuk meningkatkan kepatuhan Wajib Pajak dalam melaporkan SPT Tahunan tepat waktu. Karena kepatuhan Wajib Pajak Orang Pribadi secara parsial berpengaruh terhadap pencapaian target penerimaan pajak pada Kantor Wilayah DJP Nusa Tenggara (Darmawan, 2018). Oleh karena itu, tujuan dari kegiatan pengabdian ini antara lain (a) memberikan bekal keterampilan penggunaan e-Filing kepada mahasiswa Relawan Pajak; (b) memberikan pengetahuan dan pemahaman penggunaan e-Filing kepada Wajib Pajak; dan (c) meningkatkan kepatuhan Wajib Pajak. Kegiatan pengabdian ini dilakukan dengan proses Perekrutan, Pelatihan, Penugasan, dan Evaluasi Relawan Pajak.

\section{ANALISIS PERMASALAHAN}

Kendala yang sering dihadapi oleh Wajib Pajak dalam penggunaan e-Filing adalah lupa EFIN, email, dan jaringan internet yang tidak lancar. Electronic Filing Identification Number atau EFIN merupakan nomor identitas Wajib Pajak untuk melakukan transaksi elektronik dengan DJP. Wajib Pajak yang tidak mengetahui atau lupa EFIN tidak dapat mengakses situs DJP Online, termasuk aplikasi e-Filing. Untuk memperoleh EFIN, Wajib Pajak harus melakukan permohonan aktivasi terlebih dahulu dengan mengisi Formulir Permohonan EFIN dan dilakukan oleh Wajib Pajak Orang Pribadi yang bersangkutan tidak diperkenankan untuk dikuasakan kepada pihak lain. Peraturan Direktur Jenderal Pajak Nomor PER-06/PJ/2019 mengatur bahwa dalam hal Wajib Pajak lupa EFIN, Wajib Pajak dapat memperoleh kembali EFIN dengan cara menghubungi Kantor Layanan Informasi Perpajakan melalui saluran yang disediakan oleh DJP atau dengan mengajukan permohonan cetak ulang EFIN dengan mendatangi secara langsung KPP, KP2KP atau tempat tertentu di luar kantor sesuai dengan kewenangannya.

Selain lupa EFIN, keluhan Wajib Pajak lainnya adalah lupa e-mail. Pada saat permohonan aktivasi EFIN, Wajib Pajak diminta untuk mencantumkan alamat e-mail aktif sebagai sarana komunikasi terkait pelaksanaan hak dan kewajiban perpajakan. Proses akhir untuk mengaktivasi akun DJP Online adalah dengan mengklik link aktivasi yang dikirimkan ke alamat email Wajib Pajak tersebut. Untuk permasalahan jaringan internet yang tidak lancar, internal DJP senantiasa membenahi berbagai kendala dan gangguan sistem DJP Online. Tidak lancarnya internet saat penggunaan $e-$ Filing berhubungan dengan traffic dan kapasitas yang terjadi menjelang akhir batas pelaporan. Sehingga dengan slogan Lebih Awal Lebih Baik, diharapkan Wajib Pajak dapat menghindari kendala jaringan internet saat pelaporan SPT secara online.

\section{SOLUSI YANG DITAWARKAN}

Menurut OECD tahun 2015 di dalam Kajian Relawan Pajak tahun 2018, faktor pengetahuan dan kesadaran masyarakat adalah salah satu penyebab rendahnya kepatuhan masyarakat membayar pajak. Untuk itu, Direktorat Jenderal Pajak (DJP) membutuhkan sentuhan Akademisi yang peduli 
terhadap nasib bangsa dan negara Indonesia untuk bersama DJP berkontribusi memberikan pengetahuan dan menggugah kesadaran masyarakat untuk membayar pajak, salah satunya melalui kegiatan Relawan Pajak. Pada program Relawan Pajak dalam pengabdian ini, mahasiswa/i dipersiapkan untuk membantu Wajib Pajak dalam pelaporan SPT Tahunan PPh Orang Pribadi melalui e-Filing. Sehingga Wajib Pajak tidak menemui kendala seperti lupa EFIN, e-mail, dan jaringan internet yang tidak lancar saat diasistensi oleh Relawan Pajak. Adapun tahapan-tahapan yang dilakukan antara lain sebagai berikut.

\section{Tahap Perekrutan}

Pada tahapan awal ini, Tax Center Universitas Mataram melakukan koordinasi dengan Kanwil DJP Nusra terkait dengan kebutuhan Relawan Pajak dan lokasi asistensi. Setelah didapatkan informasi yang cukup, kegiatan selanjutnya adalah melakukan publikasi rekrutmen Relawan Pajak kepada mahasiswa/i semester akhir. Proses seleksi dilakukan terhadap Calon Relawan Pajak berupa wawancara dan persyaratan administratif. Informasi mengenai kelulusan pada tahap seleksi dilakukan dengan memberikan pengumuman Relawan Pajak.

\section{Tahap Pelatihan}

Setelah tahap perekrutan, Tax Center Universitas Mataram bekerjasama dengan Kanwil DJP Nusra melaksanakan pelatihan terhadap Relawan Pajak. Mahasiswa/i yang diumumkan lulus menjadi Relawan Pajak wajib menghadiri Pelatihan Relawan Pajak. Dalam pelatihan ini, Relawan Pajak diberikan materi mengenai kesadaran pajak dan pengisian SPT Tahunan Formulir 1770 SS dan 1770 S menggunakan aplikasi e-Filing serta troubleshoot dalam situs DJP Online. Selain itu, Relawan Pajak diberikan pemahaman mengenai Codes of Conduct Relawan Pajak.

Pada tahapan ini, dilakukan Leveling Test yaitu tes yang berupa pertanyaan-pertanyaan dari materi yang telah diberikan saat pelatihan. Tujuan dilakukannya Leveling Test adalah untuk menentukan kategori tugas Relawan Pajak saat penugasan. Kategori yang dimaksud antara lain Petugas Pengawas, Petugas Asistensi, Petugas Registrasi, atau Petugas Pendukung.

\section{Tahap Penugasan}

Dari hasil penetapan kategori dan lokasi asistensi, Tax Center Universitas Mataram berkoordinasi dengan Kanwil DJP Nusra untuk memastikan kelancaran selama Relawan Pajak melaksanakan penugasan. Relawan Pajak ditugaskan di beberapa KPP di bawah Kanwil DJP Nusra. Tugas yang dilaksanakan oleh Relawan Pajak sesuai dengan kategori penugasan.

\section{Tahap Evaluasi}

Pada tahapan akhir ini, Kanwil DJP Nusra memberikan apresiasi berupa sertifikat kepada Relawan Pajak. Dari kegiatan penutupan tersebut, Tax Center Universitas Mataram melakukan evaluasi terhadap keseluruhan pelaksanaan program Relawan Pajak. Hasil evaluasi ini dijadikan sebagai bahan masukan dan perbaikan untuk kegiatan Relawan Pajak periode selanjutnya.

\section{HASIL DAN PEMBAHASAN}

Kegiatan pengabdian ini meliputi Tahap Perekrutan, Pelatihan, Penugasan, dan Evaluasi Relawan Pajak. Dari hasil tahap awal, yaitu Tahap Perekrutan diperoleh sebanyak 66 orang mahasiswa yang ditetapkan sebagai Relawan Pajak. Seluruhnya merupakan mahasiswa/i semester akhir Program Studi D3 Perpajakan Universitas Mataram. Mahasiswa/i yang dinyatakan lolos sebagai Relawan 
Pajak telah melalui proses seleksi wawancara dan pemenuhan persyaratan administratif. Proses publikasi rekrutmen, seleksi dan pengumuman dilaksanakan di Program Studi D3 Perpajakan Universitas Mataram.

Tahap kedua adalah Tahap Pelatihan untuk mempersiapkan Relawan Pajak sebelum penugasan di lapangan. Pelatihan dilaksanakan di Program Studi D3 Perpajakan Universitas Mataram dengan pemberian materi terkait kesadaran pajak dan penggunaan aplikasi e-Filing dalam pengisian SPT Tahunan Formulir 1770 SS dan 1770 S, termasuk EFIN dan troubleshoot dalam situs DJP Online. Relawan Pajak juga dibekali dengan Codes of Conduct Relawan Pajak dan diberikan pemahaman mengenai tata cara menghadapi Wajib Pajak dengan baik. Selain pemberian materi, dalam pelatihan ini dilakukan Leveling Test sebagai penentuan kategori tugas Relawan Pajak saat penugasan. Tabel 1 menunjukkan data hasil Leveling Test yang telah dilakukan kepada 66 orang Relawan Pajak berdasarkan Surat Kepala Kanwil DJP Nusra No. S-97/WPJ.31/2019.

Tabel 1. Hasil Leveling Test Relawan Pajak

\begin{tabular}{lccccc}
\multicolumn{1}{c}{ Askistensi } & $\begin{array}{c}\text { Petugas } \\
\text { Registrasi } \\
\text { (orang) }\end{array}$ & $\begin{array}{c}\text { Petugas } \\
\text { Pendukung } \\
\text { (orang) }\end{array}$ & $\begin{array}{c}\text { Petugas } \\
\text { Asistensi } \\
\text { (orang) }\end{array}$ & $\begin{array}{c}\text { Petugas } \\
\text { Pengawas } \\
\text { (orang) }\end{array}$ & $\begin{array}{c}\text { Jumlah } \\
\text { (orang) }\end{array}$ \\
\hline $\begin{array}{l}\text { KPP Pratama } \\
\text { Mataram }\end{array}$ & 4 & 4 & 18 & 2 & 28 \\
$\begin{array}{l}\text { Barat } \\
\text { KPP Pratama }\end{array}$ & 2 & 2 & 13 & 2 & 19 \\
$\begin{array}{l}\text { Mataram } \\
\text { Timur }\end{array}$ & 2 & 2 & 13 & 2 & 19 \\
$\begin{array}{l}\text { KPP Pratama } \\
\text { Praya } \\
\text { Jumlah } \\
\text { (orang) }\end{array}$ & 8 & 8 & 44 & 6 & 66 \\
\hline Sumber & & & & &
\end{tabular}

Sumber: Data primer diolah (2019)

Berdasarkan data pada Tabel 1, pelaksanaan Tahap Penugasan Relawan Pajak ditempatkan di 3 lokasi asistensi, yaitu KPP Pratama Mataram Barat sebanyak 28 orang, KPP Pratama Mataram Timur sebanyak 19 orang, dan KPP Pratama Praya sebanyak 19 orang. Sebelum penugasan di lokasi asistensi, Relawan Pajak ditugaskan dalam kegiatan Help Desk Pengisian SPT Tahunan PPh Orang Pribadi untuk ASN di lingkungan Universitas Mataram. Kegiatan ini diadakan di Gedung Rektorat Universitas Mataram dengan Wajib Pajak yang mengikuti kegiatan sebanyak 151 orang Wajib Pajak. Kegiatan Help Desk ini berjalan dengan baik, seluruh Wajib Pajak yang berpartisipasi berhasil melaporkan SPT Tahunan PPh Orang Pribadinya melalui e-Filing.

Penugasan berlangsung selama kurang lebih 1 bulan, Relawan Pajak bertugas sesuai dengan kategori dan lokasi asistensi yang ditetapkan. Beberapa waktu Relawan Pajak beserta petugas pajak dari KPP terkait juga melakukan kunjungan ke instansi-instansi pemerintah maupun swasta untuk asistensi e-Filing, seperti Kantor Gubernur NTB, PDAM Giri Menang, LANUD, Detasemen Kesehatan, POLDA NTB, Lombok Epicentrum Mall, Transmart, dan lainnya. Pada tahapan ini, Relawan Pajak hanya diperkenankan melakukan asistensi untuk aplikasi e-Filing. Asistensi aplikasi lainnya, seperti e-Form tetap dilakukan oleh petugas pajak. Hal ini dikarenakan pada saat pelatihan Relawan Pajak hanya dibekali penggunaan aplikasi e-Filing. 
Dengan berakhirnya batas waktu pelaporan SPT Tahunan PPh Orang Pribadi maka penugasan Relawan Pajak di lokasi asistensi dinyatakan telah selesai. Kanwil DJP Nusra beserta jajarannya mengapresiasi kinerja Relawan Pajak selama penugasan dengan memberikan sertifikat dan souvenir pajak kepada Relawan Pajak. Pada Tahap Evaluasi ini diperoleh hasil bahwa dari ketiga lokasi asistensi Relawan Pajak, KPP Pratama Mataram Barat, KPP Pratama Mataram Timur, dan KPP Pratama Praya, seluruhnya dinyatakan berhasil mencapai jumlah target penerimaan SPT Tahunan melalui e-Filing.

\section{KESIMPULAN}

Kegiatan pengabdian ini berjalan dengan baik dan mendapatkan respon positif baik dari mahasiswa Relawan Pajak maupun Wajib Pajak. Mahasiswa yang ditetapkan menjadi Relawan Pajak memperoleh keterampilan dalam menggunakan aplikasi e-Filing dan pengalaman untuk pengembangan diri dan networking. Wajib Pajak yang berpartisipasi pada kegiatan asistensi ini memperoleh tambahan pengetahuan dan pemahaman penggunaan e-Filing. Dengan demikian, kepatuhan Wajib Pajak meningkat tercermin dari tercapainya target penerimaan SPT Tahunan pada 3 KPP lokasi asistensi.

Program Relawan Pajak masih perlu ditingkatkan pada tahap Pelatihan dan Penugasan. Materi yang diberikan pada Tahap Pelatihan Relawan Pajak periode selanjutnya, tidak hanya penggunaan aplikasi e-Filing saja namun ditambahkan dengan aplikasi e-Form. Karena penugasan dilaksanakan pada periode pelaporan SPT Tahunan PPh Orang Pribadi, maka Relawan Pajak perlu memiliki keterampilan penggunaan e-Form. Terkait waktu pelaksanaan penugasan, sebaiknya diperpanjang sehingga Relawan Pajak dapat memiliki waktu yang cukup dalam mengimplementasikan ilmunya.

\section{UCAPAN TERIMA KASIH}

Ucapan terima kasih kepada Kantor Wilayah Direktorat Jenderal Pajak Nusa Tenggara selaku mitra resmi Tax Center Universitas Mataram yang memfasilitasi pelaksanaan kegiatan pengabdian ini.

\section{REFERENSI}

Amrul R. 2016. Analisis Penerapan Efiling Sebagai Upaya Meningkatkan Kepatuhan Wajib Pajak Dalam Penyampaian Surat Pemberitahuan (SPT) Tahunan pada Kantor Pelayanan Pajak (KPP) Pratama Mataram Timur. Jurnal IImiah Rinjani, 4(4).

Darmawan A. 2018. Analisis Pengaruh Kepatuhan Wajib Pajak Terhadap Pencapaian Target Penerimaan Pajak Pada Kanwil DJP Nusa Tenggara. Tugas Akhir Program Magister, Universitas Terbuka.

Direktorat Jenderal Pajak. (2017, 27 Oktober). Surat dan Modul Relawan Pajak. Diperoleh 27 Januari 2019, dari http://edukasi.pajak.go.id/images/relawan_pajak/modul_relawan_pajak_2019.pdf

Direktorat Jenderal Pajak. (2018, 23 Agustus). Kebijakan Perpajakan Sehubungan Dengan Bencana Alam Gempa Bumi Di Pulau Lombok. Diperoleh 27 Januari 2019, dari https://pajak.go.id/kebijakan-perpajakan-sehubungan-dengan-bencana-alam-gempa-bumidi-pulau-lombok

Direktorat Jenderal Pajak. (2019, 27 Maret). Peraturan Direktur Jenderal Pajak Nomor PER-06/PJ/2019. Diperoleh 20 April 2019, dari https://pajak.go.id/id/peraturan-direktur-jenderal-pajak-nomor-06pj2019

Kementerian Keuangan Republik Indonesia. (2019, 1 Januari). Buku I Rancangan Undang-Undang Tentang Anggaran Pendapatan Dan Belanja Daerah. Diperoleh 15 Maret 2019, dari http://www.kemenkeu.go.id/media/10378/ruu-apbn-2019.pdf

Kementerian Pendayagunaan Aparatur Negara dan Reformasi Birokrasi. (2017, 16 Maret). Surat Edaran Menpan Nomor 24 Tahun 2017. Diperoleh 15 Maret 2019, dari https://jdih.menpan.go.id/puu-155-Surat\%20Edaran\%20Menpan.html 